\title{
Serum pregnancy-associated plasma protein A levels in the first, second and third trimester of pregnancy: relation to newborn anthropometric parameters and maternal tobacco smoking
}

\author{
Magdalena Chełchowska1 ${ }^{1}$, Joanna Gajewska ${ }^{1}$, Joanna Mazur ${ }^{2}$, Jadwiga Ambroszkiewicz ${ }^{1}$, \\ Tomasz M. Maciejewski ${ }^{3}$, Jerzy Leibschang ${ }^{4}$
}

\begin{abstract}
${ }^{1}$ Screening Department, Institute of Mother and Child, Warsaw, Poland 2Department of Child and Adolescent Health, Institute of Mother and Child, Warsaw, Poland

${ }^{3}$ Department of Obstetrics and Gynecology, Institute of Mother and Child, Warsaw, Poland

${ }^{4}$ Department of Obstetrics, Warsaw Medical University, Warsaw, Poland
\end{abstract}

Submitted: 10 October 2014

Accepted: 2 February 2015

Arch Med Sci 2016; 12, 6: 1256-1262

DOI: 10.5114 /aoms.2016.62908

Copyright @ 2016 Termedia \& Banach

\section{Abstract}

Introduction: The purpose of this study was to evaluate the associations of the first, second and third trimester serum pregnancy-associated plasma protein A (PAPP-A) concentrations with neonatal anthropometric parameters. The effect of tobacco smoking during pregnancy on PAPP-A level was also studied.

Material and methods: One hundred and fifty healthy pregnant women were divided into smoking and tobacco-abstinent groups. Serum PAPP-A level was measured with the KRYPTOR rapid random-access immunoassay analyzer. The relationship between PAPP-A and newborn related outcome as well as markers of estimated intensity of cigarette smoking was evaluated by univariate and multivariate linear regression.

Results: Pregnancy-associated plasma protein A concentration was positively correlated with birth weight in the first $(\beta=31.6 ; p<0.001)$, second $(\beta=$ $10.6 ; p<0.05)$, and third $(\beta=4.6 ; p<0.001)$ trimester of gestation. A significant association between PAPP-A and birth body length and head circumference in the second $(\beta=0.02 ; p<0.05)$ and third trimester $(\beta=0.01$; $p<0.01$ ) was also found. The serum PAPP-A levels were significantly lower in the smoking than in the tobacco-abstinent group in each trimester of pregnancy $(p<0.001)$. The largest impact of the number of cigarettes smoked per day on PAPP-A level was found in the second $(\beta=-1.2 ; p=0.004)$ and third trimester $(\beta=-2.6 ; p=0.001)$.

Conclusions: Maternal serum PAPP-A levels during gestation might be significant predictors for birth weight. Increased PAPP-A concentrations in the second and third trimester appeared to also be predictive for newborn body length and head circumference. Smoking alters maternal PAPP-A levels in all trimesters, with the greatest impact related to the number of cigarettes smoked per day.

Key words: pregnancy-associated plasma protein A, tobacco smoking, pregnancy, birth weight, birth body length, head circumference.

\section{Corresponding author:} Magdalena Chełchowska $\mathrm{MD}, \mathrm{PhD}$

Screening Department Institute of Mother and Child

17A Kasprzaka St

01-211 Warsaw, Poland

Phone: +48 223277260

E-mail: magdalena.

chelchowska@imid.med.pl 


\section{Introduction}

The proteinase pregnancy-associated plasma protein A (PAPP-A) belongs to the metzincin superfamily of metalloproteinases and is originally isolated from the serum of pregnant women. While this high molecular weight glycoprotein is produced in great amounts by trophoblast and deciduas cells, it is also found in other cells (fibroblasts, osteoblasts, vascular smooth muscle cells, ovarian granulose cells) in different concentrations [1-5]. During pregnancy PAPP-A concentrations increase, and it is detectable in maternal blood from the $28^{\text {th }}$ day after conception [6]. At present, serum level of PAPP-A are widely used in prenatal screening as an indicator of certain genetic disorders in the fetus [7-10]. However, recent studies documented that pregnancy-associated plasma protein A modulates insulin-like growth factor (IGF) bioavailability by specific cleavage of antagonizing IGF-binding protein (IGFBP), especially IGFBP-4 and IGFBP-5, and thereby may promote fetal growth and development [5, 11, 12]. Low concentrations of PAPP-A during gestation may result in inadequate expression of insulin-like growth factors in the syncytiotrophoblast leading to utero-placental insufficiency, and can be a risk factor for many health complications for the mother and child [12-17]. Low levels of this protein were associated with preterm delivery, placental abruption, intrauterine growth restriction, and low birth weight [17-19]. The associations between low values of first trimester maternal PAPP-A and fetal biometry are well known, but there are not many studies concerning the effect of late pregnancy PAPP-A on birth weight [20-23]. Cigarette smoking during pregnancy has been identified as a significant predictor of lower birth weight, but the mechanism has not been adequately clarified [24-26]. Smoking has been shown to reduce maternal serum PAPP-A levels probably due to placental insufficiency. As a result a reduction of fetal growth occurs as a consequence of disorder in the insulin-like growth factor axis [13, 21, 27-29].

To our knowledge, minimal data exist concerning the relationship between PAPP-A levels during pregnancy, markers of estimated intensity of cigarette smoking, and neonatal anthropometric parameters. The purpose of this study was to evaluate the implications of the first, second and third trimester serum PAPP-A concentrations for neonatal birth weight, length, and head circumference. In addition, the effect of tobacco smoking during pregnancy on level of this protein was also studied.

\section{Material and methods}

It was a study comparing two groups, taken from a prospective observational study for ad- verse effects of tobacco smoking in pregnant women regularly visiting the Department of Obstetrics and Gynecology, Institute of Mother and Child and the Warsaw Medical University between January 2010 and March 2012. All pregnant volunteers were informed of the study objectives and signed a written informed consent form. The study was carried out according to the principles of the Declaration of Helsinki and was approved by the Ethical Committee of the Institute of Mother and Child.

Healthy pregnant women enrolled in the study had structurally normal, uncomplicated singleton pregnancies and were in the first trimester of pregnancy. Gestational age was determined from the last menstrual period and confirmed or corrected by ultrasonographic measurements of the crown-rump length. The exclusion criteria were: pregnancies with more than one fetus and those which showed fetal structural anomalies, preeclampsia, hypertension, diabetes mellitus, active hepatitis, renal and cardiovascular diseases, inflammatory conditions, and infertility treatment. All of the subjects lived in an urban area, none of the mothers reported drinking alcohol, and none of the fetuses showed abnormalities.

At the first control visit, a history of smoking was obtained by direct questioning of the pregnant women. Smokers were defined as those women who reported their smoking habit as maintained at a rate of at least 5 cigarettes per day and at least 2 years before conception. Non-smokers were defined as those women who had never smoked and were not exposed to environmental tobacco smoke during their pregnancy (smoking spouse or co-workers).

The base study population, in which the present study was nested, constituted 498 singleton pregnancies. In the study group we included 70 subjects who had hospital visits in the first, second and third trimester of pregnancy and continued smoking during pregnancy. The control cohort consisted 80 tobacco-abstinent healthy pregnant women similar in age and age of gestation. The classification was confirmed by measurement in pregnant women of serum cotinine concentration - the major metabolite of nicotine. A cut-off value of $\geq 13.7 \mu \mathrm{g} / \mathrm{l}$ was used to separate smokers from non-smokers, in accordance with others studies [22].

After birth clinical information on the infants, including weight, body length, and head circumference, was completed.

Peripheral blood was taken once in each trimester of pregnancy. Blood was collected in the usual manner. In order to obtain serum, the blood was centrifuged at $2500 \times \mathrm{g}$, at $4^{\circ} \mathrm{C}$ for $10 \mathrm{~min}$ and was stored for subsequent biochemical analysis. 
Table I. Clinical and biochemical characteristics of the study population

\begin{tabular}{|c|c|c|}
\hline Characteristics & Non-smoking & Smoking \\
\hline Number & 70 & 80 \\
\hline Age $\left[\right.$ years] ${ }^{1}$ & $29.5 \pm 0.6$ & $30.6 \pm 0.5$ \\
\hline Ethnic origin: Caucasian (\%) & 100 & 100 \\
\hline \multicolumn{3}{|l|}{ Gestational age [week]: } \\
\hline Trimester I & $12.6 \pm 0.9$ & $12.4 \pm 0.9$ \\
\hline Trimester II & $21.8 \pm 1.5$ & $21.6 \pm 1.5$ \\
\hline Trimester III & $31.4 \pm 1.4$ & $31.5 \pm 1.3$ \\
\hline $\begin{array}{l}\text { Gestational age of birth } \\
\text { [weeks] }\end{array}$ & $38.9 \pm 0.1$ & $38.7 \pm 0.2$ \\
\hline \multicolumn{3}{|l|}{ Delivery, $n(\%):$} \\
\hline $\begin{array}{l}\text { Normal vaginal/ } \\
\text { Cesarean }\end{array}$ & $\begin{array}{c}75(93.8) / \\
5(6.2)\end{array}$ & $\begin{array}{c}66(94.2) / \\
4(5.8)\end{array}$ \\
\hline Emergency cesarean & $2(2.5)$ & $2(2.9)$ \\
\hline $\begin{array}{l}\text { Neonatal gender, } \\
\text { female/male, } n\end{array}$ & $31 / 49$ & $29 / 41$ \\
\hline \multicolumn{3}{|l|}{ Birth weight $[\mathrm{g}]^{1}$ : } \\
\hline Whole group & $3529 \pm 52$ & $3167 \pm 55^{\star * *}$ \\
\hline Female & $3453 \pm 91$ & $3236 \pm 84$ \\
\hline Male & $3577 \pm 62$ & $3119 \pm 72^{* * *}$ \\
\hline \multicolumn{3}{|l|}{ Birth body length $[\mathrm{cm}]^{1}$ : } \\
\hline Whole group & $55.4 \pm 0.2$ & $54.4 \pm 0.3^{*}$ \\
\hline Female & $54.9 \pm 0.4$ & $54.2 \pm 0.4$ \\
\hline Male & $55.7 \pm 0.2$ & $54.5 \pm 0.4^{\star *}$ \\
\hline \multicolumn{3}{|l|}{ Head circumference $[\mathrm{cm}]^{1}$ : } \\
\hline Whole group & $34.5 \pm 0.1$ & $33.7 \pm 0.1^{\star * *}$ \\
\hline Female & $34.3 \pm 0.2$ & $33.6 \pm 0.2^{* * *}$ \\
\hline Male & $34.7 \pm 0.1$ & $33.8 \pm 0.2$ \\
\hline Apgar score $\left(5^{\text {th }} \mathrm{min}\right)$ & $10(10-10)$ & $10(10-10)$ \\
\hline Number of cigarettes/day ${ }^{1}$ & 0 & $8.8 \pm 0.5$ \\
\hline $\begin{array}{l}\text { Time of smoking before } \\
\text { conception [year] }{ }^{1}\end{array}$ & 0 & $8.4 \pm 0.5$ \\
\hline \multicolumn{3}{|l|}{ Cotinine $[\mu \mathrm{g} / \mathrm{l}]^{2}:$} \\
\hline Trimester I & 0 & $\begin{array}{c}63.6 \\
(46.3-126.7) \\
\end{array}$ \\
\hline Trimester II & 0 & $\begin{array}{c}64.3 \\
(46.2-144.4) \\
\end{array}$ \\
\hline Trimester III & 0 & $\begin{array}{c}62.7 \\
(44.7-127.3) \\
\end{array}$ \\
\hline \multicolumn{3}{|l|}{ PAPP-A [IU/I] $]^{1}:$} \\
\hline Trimester I & $2.92 \pm 0.23$ & $5.34 \pm 0.28^{* * *}$ \\
\hline Trimester II & $28.88 \pm 1.63$ & $44.63 \pm 1.89^{\star \star *}$ \\
\hline Trimester III & $56.09 \pm 3.19$ & $89.15 \pm 4.13^{* * *}$ \\
\hline \multicolumn{3}{|l|}{ PAPP-A $(M \circ M)^{2}$ : } \\
\hline Trimester I & $\begin{array}{c}0.76 \\
(0.53-2.07) \\
\end{array}$ & $\begin{array}{c}1.20 \\
(0.68-2.31)^{\star \star \star}\end{array}$ \\
\hline Trimester II & $\begin{array}{c}0.75 \\
(0.58-1.99) \\
\end{array}$ & $\begin{array}{c}1.21 \\
(0.92-2.34)^{\star \star *}\end{array}$ \\
\hline Trimester III & $\begin{array}{c}0.85 \\
(0.61-2.05)\end{array}$ & $\begin{array}{c}1.28 \\
(1.05-2.78)^{\star \star \star}\end{array}$ \\
\hline
\end{tabular}

${ }^{1}$ Values are means $\pm S E M,{ }^{2}$ values are median and interquartile range (IQR $10^{\text {th }}-90^{\text {th }}$ percentiles); MoM - multiples of the median, $P A P P-A-$ pregnancy-associated plasma protein $A ;{ }^{*} P=0.004$ ${ }^{\star *} p=0.009 ;{ }^{* * *} p<0.001$.
Cotinine levels in serum were determined by the immunoenzymatic method using a commercially available kit (Cotinine one-step ELISA, Calbiotech Inc., Spring Valley, CA, USA). Serum concentrations of PAPP-A were measured with the KRYPTOR rapid random-access immunoassay analyzer (Brahms $\mathrm{GmbH}$, Hennigsdorf, Germany) using time-resolved amplified cryptate emission technology (TRACE).

\section{Statistical analysis}

The results were presented as means with standard error of the mean (SEM) for normally distributed data or median with interquartile range $\left(10^{\text {th }}-90^{\text {th }}\right.$ percentiles) for non-normally distributed variables. The results of PAPP-A were also given as multiples of medians (MoMs) relative to values recorded for normal pregnancies at specific weeks. The normality of data was tested using the Kolmogorov-Smirnov test. In the smoking and non-smoking groups, the baseline characteristics were compared using the $t$-test for normally distributed data and the non-parametric Mann-Whitney $U$ test for non-normally distributed variables. Spearman's correlation coefficient was calculated to determine the association between the studied markers. The relationship between PAPP-A and newborn related outcome as well as markers of estimated intensity of cigarette smoking was evaluated using both univariate and multivariate linear regression. In the multivariate model, the forward selection method was used. The results of linear regression were presented as the regression coefficient ( $\beta$ ) with $95 \%$ confidence interval $(95 \% \mathrm{Cl})$, its significance and the $R^{2}$ goodness-of-fit statistic $\left(R^{2}\right)$ expressed as a percentage of explained variability in the dependent variable. A $p$-value $<0.05$ was considered statistically significant. Data analyses were performed using SPSS version 17.1 (SPSS INC., Chicago, IL., USA).

\section{Results}

Table I summarizes some of the clinical and biochemical features of this study population and neonatal outcomes broken down by smoking status. There were no significant differences between the groups with respect to ethnic origin, neonatal gender, mean gestational age at delivery or way of delivery. In tobacco-abstinent women, an emergency cesarean section was performed in $2.9 \%$ of cases (all cesarean deliveries constituted $5.8 \%-2$ performed upon request and 2 due to large baby weight), whereas in smoking pregnant women the rate of emergency cesarean section was 2.5\% (all cesarean deliveries constituted 6.2\% - 3 performed upon request and 2 due to abnormal presentation). Maternal characteristics were 
comparable in both groups except for cigarette smoking habits. The mean number of cigarettes per day for smokers was 8.8 , and the mean duration of smoking before conception was 8.4 years. In the group of smoking mothers, serum cotinine concentrations were in the range $46.3-144.4 \mu \mathrm{g} / \mathrm{l}$ and correlated positively with the daily number of cigarettes consumed ( $r=0.70 ; p=0.009)$. In the tobacco-abstinent group, serum cotinine was present only in 2 women in trace amounts $(1.2 \mu \mathrm{g} / \mathrm{l}$ and $5.9 \mu \mathrm{g} / \mathrm{l})$. There were no complications during delivery in either group. Mean birth weight, body length, and head circumference of the smoking mothers' infants were significantly lower $(p<0.001 ; p=0.004 ; p=0.009$, respec- tively) compared with the abstinent group. Apgar score was similar in the two groups. There was a statistically significant difference of PAPP-A values expressed in IU/I as well as in MoM in the studied groups in all trimesters of pregnancy $(p<$ 0.001) (Table I).

Table II shows the results of univariate and multivariate linear regression analyses, regression coefficient $(\beta)$, and $p$-value. As dependent variables birth weight, birth body length and head circumference were used. In the univariate model, PAPP-A levels in the second and third trimester were significant predictors of all three studied factors. PAPP-A concentration in the first trimester was a significant predictor of only birth weight.

Table II. Univariate and multivariate analysis of neonatal birth weight, body length and head circumference predictors $(n=150)$

\begin{tabular}{|c|c|c|c|c|c|c|}
\hline \multirow[t]{2}{*}{ Variable } & \multicolumn{3}{|c|}{ Univariate analysis } & \multicolumn{3}{|c|}{ Multivariate analysis } \\
\hline & $\beta$ & $95 \% \mathrm{Cl}$ & $P$-value & $\beta$ & $95 \% \mathrm{Cl}$ & $P$-value \\
\hline \multicolumn{7}{|l|}{ Neonatal birth weight: } \\
\hline Maternal age [years] & -13.5 & $-31.5 / 4.3$ & 0.135 & & & \\
\hline Gestational age [weeks] & 167.7 & $110.0 / 225.5$ & $<0.001$ & 145.8 & $89.7 / 202.0$ & $<0.001$ \\
\hline Fetal gender $($ female $=0 ;$ male $=1)$ & 20.0 & $-143.3 / 183.3$ & 0.809 & & & \\
\hline Smoking status (no $=0 ;$ yes $=1$ ) & -361.5 & $-510.8 /-212.5$ & $<0.001$ & -230.3 & $-89.7 /-77.1$ & 0.003 \\
\hline PAPP-A1 [U/I] & 31.6 & $0.19 / 63.0$ & 0.049 & & & \\
\hline PAPP-A2 [U/I] & 10.5 & $6.2 / 14.8$ & $<0.001$ & 5.0 & $0.5 / 9.5$ & 0.030 \\
\hline PAPP-A3 [U/I] & 4.6 & $2.6 / 6.7$ & $<0.001$ & & & \\
\hline \multicolumn{7}{|l|}{ Neonatal body length: } \\
\hline Maternal age [years] & -0.04 & $-0.11 / 0.04$ & 0.332 & & & \\
\hline Gestational age [weeks] & 0.69 & $0.44 / 0.93$ & $<0.001$ & 0.69 & $0.44 / 0.94$ & $<0.001$ \\
\hline Fetal gender $($ female $=0 ;$ male $=1)$ & 0.55 & $-0.13 / 1.25$ & 0.109 & 0.71 & $0.08 / 1.34$ & 0.028 \\
\hline Smoking status (no = 0 ; yes $=1$ ) & -0.99 & $-1.66 /-0.33$ & 0.004 & -0.75 & $-1.38 /-0.13$ & 0.018 \\
\hline PAPP-A1 [U/I] & -0.12 & $-0.01 / 0.26$ & 0.076 & & & \\
\hline PAPP-A2 [U/I] & 0.02 & $0.00 / 0.04$ & 0.018 & & & \\
\hline PAPP-A3 [U/I] & 0.01 & $0.00 / 0.02$ & 0.007 & & & \\
\hline \multicolumn{7}{|l|}{ Neonatal head circumference: } \\
\hline Maternal age [years] & -0.22 & $-0.06 / 0.02$ & 0.353 & & & \\
\hline Gestational age [weeks] & -0.38 & $0.22 / 0.50$ & $<0.001$ & 0.33 & $0.19 / 0.47$ & $<0.001$ \\
\hline Fetal gender $($ female $=0 ;$ male $=1)$ & 0.09 & $-0.31 / 0.48$ & 0.656 & & & \\
\hline Smoking status $($ no $=0 ;$ yes $=1)$ & -0.85 & $-1.21 /-0.48$ & $<0.001$ & -0.73 & $-1.08 /-0.38$ & $<0.001$ \\
\hline PAPP-A1 [U/I] & 0.07 & $-0.01 / 0.14$ & 0.082 & & & \\
\hline PAPP-A2 [U/l] & 0.02 & $0.01 / 0.03$ & $<0.001$ & & & \\
\hline PAPP-A3 [U/I] & 0.01 & $0.00 / 0.01$ & 0.001 & & & \\
\hline
\end{tabular}

PAPP-A - pregnancy-associated plasma protein A, PAPP-A1 - PAPP-A level in the first trimester, PAPP-A2 - PAPP-A level in the second trimester, PAPP-A3-PAPP-A level in the third trimester, $95 \% \mathrm{Cl}$-confidence interval presented as lower limit/upper limit. 
In the model predicting birth weight, the value of $\beta$ coefficient of the variable PAPP-A steadily decreased (31.6 vs. 10.5 vs. 4.6) for determinants in subsequent trimesters, which means that the effect obtained in the first trimester had a greater impact. In multivariate analysis, independent predictors of neonatal anthropometric factors were identified. Gestational age (coding as a continuous variable) and tobacco smoking status (dummy coding) were qualified in all three models. Serum PAPP-A level in the second trimester was found to be an important predictor of birth weight, whereas fetal gender was found to be another predictor of neonatal body length. Based on the $R^{2}$ coefficient, those three models explained $31.1 \%$ of the variability in birth weight, $23.3 \%$ of the variability in body birth length and $24.4 \%$ of the variability in newborn head circumference, respectively. The correlation between PAPP-A value and the variables qualified in the final models can explain the different results in univariate and multivariate analysis (particularly the strong correlation of PAPP-A with tobacco smoking status). Additionally, we used models of linear regression to estimate the impact of intensity of cigarette smoking markers on PAPP-A levels for smoking women only. For PAPP-A serum level, the greatest impact of cigarettes smoked per day was found in the second $\left(\beta=-1.19, p=0.004, R^{2}=11.5 \%\right)$ and third trimester $\left(\beta=-2.62, p=0.001, R^{2}=10.2 \%\right)$. The model of linear regression for concentration of this protein in the second trimester also showed a significant association with time of smoking before conception ( $\beta=-1.04, p=0.007, R^{2}=10.2 \%$ ).

\section{Discussion}

The results of this study demonstrate a significant relationship between serum maternal level of pregnancy-associated protein $A$ and studied anthropometric parameters of newborns and confirmed the negative effect of tobacco smoking on this protein. Thus, PAPP-A can be an important fetal growth regulatory factor through its ability to proteolyse insulin growth factor binding proteins and thus regulate IGF bioavailability in several biological fluids. Recent studies on maternal PAPP-A and birth weight have had conflicting results. Given its mechanism for inhibition of IGF action during pregnancy, a direct relationship between maternal PAPP-A and infant anthropometric parameters may have been expected. In some studies, a positive correlation was found; however, other investigators have observed no association between maternal protein $\mathrm{A}$ and birth weight $[10,12,20,21,30,31]$. Most surprisingly, Senses et al. [4] found a significant negative correlation between PAPP-A levels and birth weight, but the authors measured this protein level only in cord blood and speculated that this protein affected the length of newborns more strongly than weight. Generally, birth weight prediction has been tested by a combination of PAPP-A, free $\beta$-human chorionic gonadotrophin ( $\beta$-hCG) and nuchal translucency (NT) in the first trimester of pregnancy. Some clinical data demonstrate a significant contribution of all three markers in a linear model of birth weight prediction, while in others only PAPP-A provided a significant contribution $[18,21,32]$. According to our knowledge, there are no published data regarding the relationship between PAPP-A measurement in each trimester and birth weight, length, and head circumference. Atis et al. [12] observed a strong positive association between PAPP-A and birth weight in women with preeclampsia and HELLP syndrome in the third trimester of pregnancy. We found that PAPP-A concentrations in the second and third trimester were significant predictors of all three anthropometric parameters, but in the first trimester PAPP-A was a significant predictor for birth weight only. The greater impact of PAPP-A obtained in the second trimester in multivariate analysis confirms the positive influence of this protein on birth weight.

Despite the fact that in recent years a decrease in the number of active smokers has been observed and knowledge of the adverse health effects of smoking during pregnancy is widespread, many adolescents at reproductive age and pregnant women in Poland continue to smoke [33]. Our study confirmed this observation. Despite the educational activation conducted at each hospital visit, many women continue smoking in the following trimesters of pregnancy. There is strong evidence that smoking during pregnancy is the most important risk factor for low birth weight $[24,25,34]$. Research on this effect has been conducted for many years, but the mechanisms by which this occurs still remain unclear. Toxic constituents of tobacco smoke alter blood flow to the placenta, and change the balance between cytotrophoblast proliferation and differentiation. Morphological damage of the villous trophoblast and in consequence a higher number of placenta areas with syncytiotrophoblastic necrosis in smokers could lead to functional interferences of this organ $[8,16,24,25]$. It may result in inadequate expression of PAPP-A and IGF axis disorders, reduced active transport of essential nutrients to the fetus, and lead to disturbances of embryogenesis and in consequence fetal growth [14, 35]. It is widely accepted that serum concentrations of PAPP-A in smoking pregnant women in the first trimester are 15-25\% lower than those observed in tobacco-abstinent groups $[8,9,24,27,29,32$, 36], but only Spencer and Covans [23] have examined the level of this protein in the second trimes- 
ter of pregnancy. The authors found a small but significant decrease of $10 \%$ in the PAPP-A MoM of smokers. In the present study, PAPP-A concentrations expressed in IU/I as well as in MoM were significantly lower in the smoking group in each trimester of pregnancy. Also a dose-related PAPP-A/cigarette smoking relationship has been found in a few studies [22, 23, 29, 37]. Some authors have observed a significant negative correlation between maternal PAPP-A levels in the first trimester and the number of cigarettes smoked per day [29]. However, in our previous, pilot study, similarly to other studies, this association was not confirmed, but a tendency to lower concentrations of this protein with longer smoke exposure and more cigarettes smoked was observed [27, 36, 38]. Yigiter et al. [37] reported that a decrease in PAPP-A was only found in women who smoked more than five cigarettes a day. Also, Spencer et al. [36] previously documented the lowest levels of this protein in women who smoked more than 15 cigarettes per day. A recent analysis, comparable to the new findings of Spencer and Cowans [22], showed a significant inverse association between cigarette dose and PAPP-A concentrations and a direct relationship between cigarette dose and cotinine levels. Moreover, the strongest impact of the number cigarettes smoked per day on serum level of PAPP-A from the second trimester, when fetal growth is the most intensive, seems to confirm our results concerning the role of this protein as a predictor of newborns' anthropometric parameters.

The present study has several limitations. We had a relatively small number of participants, especially in the tobacco smoking pregnant group. However, both studied groups were similar for age, gestational age, and ethnicity, which are recognized as important factors for PAPP-A levels [12, $18,21]$. With the enrolment method we used, we did not achieve the percentage of smokers representative of a normal pregnant population. However, we were able to compare groups that did not differ in terms of their size and basic characteristics (listed above). The applied research scheme is not typical for a case-control study with retrospective assumptions [39]. This is a prospective comparison of cohorts exposed and not exposed to the effect of one factor, in this case tobacco smoking. The advantage that offsets the above limitations is the ability to track changes in the level of PAPP-A and influence of smoking on this protein in all trimesters of pregnancy. Secondly, we did not measure serum IGF and IGFBP concentrations parallel to PAPP-A measurement in each trimester of pregnancy, which would have added information for interpreting the PAPP-A/IGFs axis and fetal growth. However, on the basis of our preliminary study conducted on a smaller than present group of women in the first trimester of pregnancy, we may suggest the essential function of this protein as a protease and regulator in the IGF system [27].

In conclusion, this study shows that maternal serum PAPP-A levels in all the studied trimesters of pregnancy might be significant predictors for birth weight. Increased pregnancy-associated plasma protein A concentration in the second and third trimester appeared to also be predictive for newborn body length and head circumference. In addition, smoking alters maternal levels of PAPP-A in all three trimesters, with the greatest impact related to the number of cigarettes smoked per day. The effect of maternal tobacco exposure on this protein during pregnancy could negatively impact fetal growth and development.

\section{Acknowledgments}

This work was supported by a grant from the Ministry of Science and Higher Education - NN 404131536 - Warsaw, Poland.

\section{Conflict of interest}

The authors declare no conflict of interest.

\section{References}

1. D’Elia P, Marzioni D, Castellucci M, Mocci C, Pala A. Homodimeric pregnancy-associated plasma protein-A in normal human placenta of first and third trimester of pregnancy: biochemical and morphological observations. Placenta 2012; 33: 942-45.

2. Li Y, Zhou Ch, Zhu X, Li L, Hui R. Pregnancy-associated plasma protein A predicts adverse vascular evens in patients with coronary heart disease: a systematic review and meta-analysis. Arch Med Sci 2013; 9: 389-97.

3. Wlazeł RN, Rysz J, Paradowski M. Examination of serum pregnancy-associated plasma protein A clinical value in acute coronary syndrome prediction and monitoring. Arch Med Sci 2013; 9: 14-20.

4. Senses DA, Coskun A, Kiseli M, et al. Is there a relationship between cord blood pregnancy-associated plasma protein $A$ and birth weight and length? Early Hum Dev 2007; 83: 479-82.

5. Boldt HB, Conover CA. Pregnancy-associated plasma protein-A (PAPP-A): a local regulator of IGF bioavailability through cleavage of IGFBPs. Growth Horm IGF Res 2007; 17: 10-8.

6. Kulaksizoglu S, Kulaksizoglu M, Kebapcilar AG, Torun AN, Ozcimen E, Turkoglu S. Can first-trimester screening program detect women at high risk for gestational diabetes mellitus? Gynecol Endocrinol 2013; 29: 137-40.

7. Poon LC, Karagiannis G, Stratieva V, Syngelaki A, Nikolaides $\mathrm{KH}$. First trimester prediction of macrosomia. Fetal Diagn Ther 2011; 29: 139-47.

8. Ardawi MS, Nasrat HA, Rouzi AA, Qari MH, Al-Qahtani $\mathrm{MH}$, Abuzenadah AM. The effect of cigarette or sheesha smoking on first-trimester markers of Down syndrome. BJOG 2007; 114: 1397-401.

9. Miron P, Cote YP, Lambert J. Effect of maternal smoking on prenatal screening for Down syndrome and trisomy 18 in the first trimester of pregnancy. Prenat Diagn 2008; 28: 180-5. 
10. Plasencia W, Gonzales Davila E, Tetilla V, Padron Perez E, Garcia Hernandez JA, Gonzales Gonzales NL. First trimester screening for large-for-gestational-age infants. Ultrasound Obstet Gynecol 2012; 39: 389-95.

11. Conover CA. Key questions and answers about pregnancy-associated plasma protein A. Trends Endocrinol Metab 2012; 23: 242-49.

12. Atis A, Aydin Y, Basol E, Kaleli S, Turgay F, Goker N. PAPP-A levels of late pregnancy in preeclampsia and HELLP syndrome. Arch Gynecol Obstet 2012; 285: 45-9.

13. Covans NJ, Spencer K. First-trimester ADAM12 and PAPP-A as markers for intrauterine fetal growth restriction through their roles in the insulin-like growth factor system. Prenat Diagn 2007; 27: 264-71.

14. D'Antonio F, Rijo C, Thilaganathan B, et al. Association between first-trimester maternal serum pregnancy-associated plasma protein-A and obstetric complications. Prenat Diagn 2013; 33: 839-47.

15. Conover CA, Bale LK, Overgaard MT, et al. Metalloproteinase pregnancy-associated plasma protein $\mathrm{A}$ is a critical growth regulatory factor during fetal development. Development 2004; 131: 1187-94.

16. Zdravkovic T, Genbacev O, McMaster MT, Fisher SJ. The adverse effects of maternal smoking on the human placenta: a review. Placenta 2005; 26 Suppl A: S81-6.

17. Loncar D, Varjacić M, Arsenijević S. Significance of pregnancy-associated plasma protein A (PAPP-A) concentration determination in the assessment of final outcome of pregnancy. Vojnosanit Pregl 2013; 70: 45-50.

18. Poon LC, Karagiannis G, Staboulidou I, Shafiei A, Nikolaides $\mathrm{KH}$. Reference range of birth weight with gestation and first trimester prediction of small-for-gestation neonates. Fetal Diagn Ther 2011; 31: 58-65.

19. Ranta JK, Raatikainen K, Romppanen J, Pulkki K, Hainonen S. Decreased PAPP-A is associated with preeclampsia, premature delivery and small for gestational age infants but not with placental abruption. Eur J Obstet Gynecol Reprod Biol 2011; 157: 48-52.

20. Leung TY, Sahota DS, Chan LW, et al. Prediction of birth weight by fetal crown-rump length and maternal serum level of pregnancy-associated plasma protein $A$ in the first trimester. Ultrasound Obstet Gynecol 2008; 31: 10-4.

21. Boucoiran I, Djemli A, Taillefer C, Rypens F, Delvin E, Audibert F. First-trimester prediction of birth weight. Am J Perinatol 2013; 30: 681-8.

22. Spencer K, Cowans NJ. Accuracy of self-reported smoking status in first trimester aneuploidy screening. Prenat Diagn 2013; 33: 116-23.

23. Spencer K, Cowans NJ. Correction of in first trimester aneuploidy screening markers for smoking status: influence of gestational age, maternal ethnicity and cigarette dosage. Prenat Diagn 2013; 33: 116-23.

24. Jauniaux E, Suri S, Muttukrishna S. Evaluation of the impact of maternal smoking on ultrasound and endocrinological markers of first trimester placenatation. Early Hum Dev 2013; 89: 777-80.

25. Jauniaux E, Burton GJ. Morphological and biological effects of maternal exposure to tobacco smoke on the feto-placental unit. Early Hum Dev 2007; 83: 699-706.

26. Gajewska J, Chelchowska M, Ceran A, Ambroszkiewicz J, Laskowska-Klita T. The influence of tobacco smoking on concentration of the pregnancy-associated plasma protein A (PAPP-A) in pregnant women. Przeg Lek 2010; 67: 1061-5.

27. Chelchowska M, Maciejewski TM, Gajewska J, Ambroszkiewicz J, Laskowska-Klita T, Leibschang J. The pregnancy-associated plasma protein-A and insulin-like growth factor system in response to cigarette smoking. J Matern Fetal Neonatal Med 2012; 25: 2377-80.

28. Sifakis S, Akolekar R, Kappou D, Mantas N, Nicolaides KH. Maternal serum IGF-I, IGFBP-1 and IGFBP-3 at 11-13 weeks in trisomy 21 and trisomy 18 pregnancies. Eur J Obstet Gynecol Reprod Biol 2011; 157: 166-8.

29. Kagan KO, Frisova V, Nicolaides KH, Spencer K. Dose de pendency between cigarette consumption and reduced maternal serum PAPP-A levels at 11-13+6 weeks of ges tation. Prenat Diagn 2007; 27: 849-53.

30. Canini S, Prefumo F, Pastorino D, et al. Association between birth weight and first-trimester free beta-human chorionic gonadotropin and pregnancy-associated plasma protein-A. Fertil Steril 2008; 89: 174-8.

31. Habayeb O, Daemen A, Timmerman D, et al. The relationship between first trimester fetal growth, pregnancy-associated plasma protein A levels and birth weight. Prenat Diagn 2010; 30: 873-8.

32. Niemimaa M, Heinonen S, Seppala M, Ryynanen M. The influence of smoking on the pregnancy-associated plasma protein $A$, free beta human chorionic gonadotropin and nuchal translucency. BJOG 2003; 110: 664-7.

33. Zatoński WA; HEM project team. Epidemiological analysis of health situation development in Europe and its causes until 1990. Ann Agric Environ Med 2012; 19: 836-41.

34. Król M, Florek E, Kornacka MK, Bokiniec R, Piekoszewski W. Clinical condition of the newborn versus tobacco smoke exposure during fetal life. Przeg Lek 2009; 66: 548-53.

35. De Leon-Luis J, Perez R, Pintado Recarte P, et al. Second trimester amniotic fluid adiponectin level is affected by maternal tobacco exposure, insulin, and PAPP-A level. Eur J Obstet Gynecol Reprod Biol 2012; 165: 189-93.

36. Spencer K, Bindra R, Cacho AM, Nicolaides KH. The impact of correcting for smoking status when screening for chromosomal anomalies using maternal serum biochemistry and fetal nuchal translucency thickness in the first trimester of pregnancy. Prenat Diag 2004; 24: 169-73.

37. Yigiter AB, Kavak ZN, Bakirci N, Gokaslan H. Effect of smoking on pregnancy-associated plasma protein $A$, free beta-human chorionic gonadotropin, and nuchal translucency in the first trimester of pregnancy. Adv Ther 2006; 23: 131-8.

38. Zhang J, Lambert-Messerlian G, Palomaki GE, Canick JA Impact of smoking on maternal serum markers and prenatal screening in the first and second trimester. Prenat Diagn 2011; 31: 583-8.

39. Marshall T. What is a case-control study? Int J Epidem 2204; 33: 612-7. 